\title{
Analysis on the Causes and Countermeasures of the Economic Predicament in the Northeast China
}

\author{
Feng Xiong \\ School of Economics, Jinan University, Guangzhou, China \\ Email: xiongfengjnu@qq.com
}

Received 5 August 2016; accepted 21 August 2016; published 25 August 2016

Copyright (C) 2016 by author and Scientific Research Publishing Inc.

This work is licensed under the Creative Commons Attribution International License (CC BY).

http://creativecommons.org/licenses/by/4.0/

(c) () D Open Access

\section{Abstract}

The economy of northeast China developed very well over the last 50 years. But now, as China steps into the "new normal", the economy of northeast China is declining rapidly. The reasons are as follows. Firstly, the secondary industry is important to northeast economy and the service sector develops slowly. Secondly, state-owned enterprises contribute too much to the development while the private enterprises are too weak. Thirdly, the only way to promote the economy in northeast is investment. Last but not least, government's investment attraction is not effective. This paper illustrates some advice to promote the economy. First of all, it may be urgent to develop tertiary industry. Second, the reform of state-owned enterprises as Temasek Holdings is inevitable. Third, the economic power should be changed from the investment-driven into innovation-driven and the investment promotion mode should also be changed.

\section{Keywords}

Rapidly Decline of Industry Transformation \& Upgrading, State-Owned-Enterprise Reform, Innovation-Driven, Invite Investment

\section{Economy Drops Rapidly in Northeast China}

Since the implementation of the revitalization strategy in the northeast region, the economic growth rate of the northeast region was above the national average level. But from 2010 to 2014, economic growth rates of Heilongjiang, Jilin, Liaoning dropped 7.2\%, 7.3\% and 8.4\% respectively, whereas national economic growth rate fell by only 3\%. In 2015, Northeast China’s economy showed a “cliff” decline [1]. 


\subsection{GDP Growth Rate in the Bottom of the Country}

In 2015, total GDP of northeast three provinces was 5 trillion and 900 billion RMB, and the increase rate was only $1 \%$ compared to that in 2014. Besides, the contribution to the national economy fell sharply, accounting for only $8.7 \%$ in the national GDP. Among them, the real GDP growth rates of Liaoning, Jilin, Heilongjiang were only $3.0 \%, 6.5 \%$ and $5.7 \%$ respectively, and nominal GDP growth rates were $-0.3 \%, 3.4 \%$ and $0.3 \%$ respectively. The real GDP growth rate of Liaoning ranked the last one among the 31 provinces while Jilin's ranked the 28th and Heilongjiang's ranked the 29th. ${ }^{1}$

\subsection{Investment in Fixed Assets Decreased Significantly}

In 2015, total investment in fixed assets in the three provinces of Northeast China was 4 trillion RMB, and it dropped $11.6 \%$ compared to 2014. The decline was particularly significant in Liaoning Province, whose total investment in fixed assets was only 1 trillion and 700 billion, dropped $27.8 \%$ compared with the previous year [1].

\subsection{Sharp Decline in Industrial Growth}

In 2015, industrial value added was $-12.7 \%$ in Liaoning Province. Heilongjiang and Jilin were $0.4 \%$ and $5.3 \%$ respectively, while in 2014, industrial values added were $-4.9 \%$ in Liaoning, $4.2 \%$ in Heilongjiang, and $4.9 \%$ in Jilin (the only province in which the industrial values added increases), indicating a serious decline in growth rate. PPI had been under the national average level continuously, and the situation of deflation is grim in industrial areas. ${ }^{1}$

\subsection{Fiscal Revenue Growth Reduced Significantly}

General public budget revenue of northeast region was 452 billion and 10 million RMB in 2015, dropped 20.6\% compared to the previous year. Among them, the general public budget revenue of Liaoning province was 212 billion and 560 million RMB, dropped 33.4\% compared to 2014. In addition, the Northeast regional government fund revenue fell by $40 \%$, which fell sharply. At the same time, the active fiscal policy required the sustained growth of fiscal expenditure inevitably. In 2015, the Northeast public fiscal expenditure reached to 1 trillion 185 billion and 700 million RMB, so as the balance of financial revenue and expenditure was hard to reach. Among them, Heilongjiang Province, in the case of the general public budget revenue, increased by $-10.5 \%$, the fiscal expenditure increased by $17.1 \%$ [2] (Table 1 ).

\section{Single Economic Structure is the Main Reason for the Economic Decline in Northeast Region}

\subsection{Single Industrial Structure, Slow Development of the Third Industry}

The Northeast China is always an important heavy industrial base since China was founded. Resource industry and heavy industry have great contribution to economic growth while the modern service industry is lagging behind. The structure of the traditional resource-based industrial and the mode of the extensive economic growth lead to the single industrial structure of the northeast of China. Mainly in the following two aspects, first, the second industry still has high proportion in the industrial structure. The GDP of the second industry accounted for $47 \%$ of the Northeast China in 2014, higher than the national average of $42.6 \%$. Service industry development is relatively slow, only accounting for $42 \%$, lower than the national average of $48.2 \%$. Secondly, heavy industry accounted for a relatively high proportion in the second industry. In 2014, heavy industry of the North-

Table 1. Economic growth and fiscal revenue growth was significantly decreased in the northeast region in 2015.

\begin{tabular}{ccccc}
\hline & Liaoning & Jilin & Heilongjiang & National average \\
Real GDP growth rate (\%) & 3.0 & 6.5 & 3.7 & 0.3 \\
Nominal GDP growth rate (\%) & 0.4 & 3.4 & 2.4 & -10.5 \\
General public budget revenue growth (\%) & -33.4 & 8.4 \\
\hline
\end{tabular}

${ }^{1}$ The data come from Wind News. 
east China accounted for the ratio remained at 78\%, higher than the average level of less than $70 \%$ of the country. Especially in Heilongjiang and Liaoning Province, heavy industry accounted for ratio were as high as $80 \%$ and $79 \%$ and more concentrated in the iron and steel, coal, oil and other industries with excess capacity, the products are mostly in bottom of the industry chain. The industrial structure with single mode and the heavy industrial enterprises with difficulty to transform and upgrade leaded to the ability to adjust to the inflation of the economy of the Northeast China are weak. With the economy of China has entered a new norm, the economic development of China generally faced with overcapacity and the problem of inadequate aggregate demand. The heavy industry is in the upstream industry chain, and it is easy to increase the production and difficult to reduce the production, which is the first to be affected. This is the reason why the northeast China with high proportion of heavy industry is inevitable to be affected by the bad economic environment. In addition, the state has introduced dozens of support policy since the revitalization in Northeast China was implement, the industrial policy still focused on the heavy industry with great development in the past, while lack to pay attention to light industry and service industry. Thus failed to fully tap the potential of light industry and service industry, and find new economic growth point [2].

\subsection{Single Economic System, Slow Development of Private Economy}

State-owned economy has been occupied the dominant position in the Northeast China. Compared with less than $20 \%$ of the country's average level, the state-owned and state holding enterprises increased value accounted for industrial added value of the proportion is as high as $67.8 \%$ in 2014 Heilongjiang province [3]. Most of the state-owned enterprises in the Northeast are the resource-based industries, which are greatly influenced by the economic cycle. With the reformation in the past 10 years, the state-owned enterprises in Northeast China have achieved fabulous results that the original state-owned enterprises accounted for nearly $70 \%$ down to about $50 \%$. In the northeast China, the central enterprises, state-owned enterprises still accounted for higher proportion than the national average level. The size of the enterprises is large. Private enterprises can only rely on the upstream and downstream of state-owned enterprises to seek for the development chance, which certainly limits the development of private enterprises and reduced the vitality of the private economy development and leaded to the slow economic development. While slowly development of the non-public sector of the economy has also led to the market mechanism difficulty to run effectively. Rigid economic system faced with the fluctuations of the economic environment, northeast area to be used as the market mechanism perfect provinces that in the short term to adjust quickly.

\subsection{The Driving Force of Economic Growth Is Single, which Is Easy to Be Affected by the Change of Investment Environment}

Before 2002, the ratio of investment in Northeast China to GDP is 30\%. After the implementation of the strategy of Northeast Revitalization from 2003 to 2010, the average annual growth rate of investment increased by more than $30 \%$ and the ratio of investment to GDP increased by $56.28 \%$ and the ratio increased to $86.6 \%$ in 2010 , higher than the national average of about $25 \%$. No matter what the growth rate of investment or investment is far higher than the national average. Dependence on investment is extremely high in the three northeastern provinces of economic growth, but with increasing pressure on the stock of real estate in recent years, the advantages of traditional northeast coal, iron and steel, petrochemical and other heavy industry development increasingly sluggish, investment on industrial reduction is directly led to one of the main reasons of the northeast economic downturn [4].

\subsection{Single Mode of Investment and the Investment Environment Created by Government Is Not Good}

Northeast China investment promotion mode is still leading by the government which leaded to single mode to create the investment environment, high investment cost, Low degree of marketization, stiff systems and cumbersome mechanisms and administrative procedures, low efficiency, resulting in much of the rent-seeking space. The relationship between government and enterprise is distorted, which leads to the dependence of local government on rent seeking and the exclusion of fine capital, which makes it difficult to achieve effective results in northeast China. Survey shows that in the period from 2001 to 2011 had in the northeast of China to carry out 
investment or the actual operation of the foreign enterprises, $66.4 \%$ of enterprises "have been stopped in northeast area management" or "in the next five years will to leave", and in these enterprises, $51.3 \%$ of the enterprise think in northeast China development experience to the maximum resistance from the local government and relevant policy, and the value in the North was $40.1 \%$, northwest of $39.9 \%$, southwest was $38.6 \%$, central of China was $29.7 \%$, East China was $18.9 \%$, South China was $17.6 \%$. In 2014, the actual utilization of foreign capital in Northeast China 40 billion 230 million RMB, an increase of 6.2\%, a significant decline compared with 2013, especially in Liaoning Province, the actual use of foreign investment 27 billion 420 million U.S. dollars, down $5.6 \%$ over the previous year. Data show that in the northeast of China, the business environment ranking the bottom, in addition to the reasons for the downturn in the economic environment, capital attraction is lead to a substantial decline in the economy of Northeast China is one of the reasons [5].

As the four reasons listed above, the main reason for the economic decline in Northeast region is the single economic structure which shows in the industrial structure, economic system, driving force of economic growth, and the mode of investment. The single economic structure has caused huge negative effects on the economy development of Northeast China, which needs to pay high attention to and take actions to solve.

\section{Exploring Diversified Development Model is the Core to Solve the Problem of Northeast Economy}

\subsection{Industrial Transformation and Upgrade, and Develop the Third Industry}

To solve the long-term development issues in the northeast region, it is necessary to accelerate the restructuring of economy, promoting the industrial restructuring and upgrading. The original focus on the revitalization of traditional heavy chemical industry is needed to change, and more attention should be paid to the development of light industry and the third industry. In promoting the "light" transformation of heavy industry, the northeast region can rely on abundant agricultural products and industrial raw materials resources to develop the light industry combined with market demand. Also, it is feasible to undertake the transfer of the advantage industrial technology in eastern coastal areas to realize industrial transformation and upgrading. To promote the third industry, the excellent advantage of snow resource and years of development experience in the northeast region can be combined, and the tourism development planning, the construction of supporting facilities, the creation of good cultural atmosphere, and the introduction of external funds should be applied to tap new economic growth point, pushing forward the development of leisure economy, in order to promote the great leap development of the third industry in the northeast region [6].

\subsection{Promote the Reform of State-Owned Enterprises, and Actively Realize the "Three Advantages"}

During July 16th to 18th in 2015, General Secretary Xi Jinping put forward 'three advantages' in the reform of state-owned enterprises when he carried out the investigation research of state-owned enterprises in Jilin Province. Namely, it is aimed to promote the reform of state-owned enterprises, which is conducive to the value maintenance and appreciation of state-owned capital, is conducive to enhancing the competitiveness of the state-owned economy, to enlarging the function of the state capital [3].

Under the guidance of the "three advantages" standards, the reform of state-owned enterprises in Northeast China can be executed from the following aspects. First of all, the innovation of state-owned assets supervision mechanism should be promoted. In terms of state-owned capital supervision system, it can learned from Singapore's Temasek model, whose success is the excellent management of the regulatory model, and to achieve a total rate of return by $16 \%$ for shareholders in more than 40 years. The Singapore Ministry of finance played a small role in the Temasek Company while it had 100\% ownership. Those really played the key role are the special company board structure, control mode of grading and progressive and effective restraint mechanism. The reformed management structure of state-owned enterprises in Northeast China can be set up with the board of directors, independent directors and executive directors.

Shareholder directors are from senior civil servants on behalf of the SASAC and the government, in order to ensure the impartiality and neutrality, their salaries are not paid by the state-owned enterprises, but paid by the government; independent directors are outstanding entrepreneur with rich business experience who were served in private enterprises or multinational companies; executive directors are from state-owned enterprises man- 
agement, and they are responsible for implementing the development strategy of the company.

In structure design, the independent directors should be accounted for the majority of the board of directors, which can not only reduce the direct intervention of the shareholders to the board of directors, reducing the impact by the government, but also the small number of executive directors can effectively separate the responsibility of decision-making, implementation and responsibility.

Northeast State-owned enterprise can specify the related articles of the company or the board of directors pointed to set different backgrounds shareholders seats, and different types of shareholders has different duties, which can effectively prevent the loss of state-owned capital and realize state-owned capital maintaining and increasing, improving the operating efficiency of the state-owned enterprises. Secondly, with developing equity diversification and the mixed ownership economy, competitive business, subsidiary enterprises, new investment projects are mainly promoted to drive the enterprise restructuring in state-owned enterprises to attract non-public capital to participate in actively, so that the mixed ownership economy can be developed, and the competitiveness of the state-owned economy can be enhanced.

At the same time, the employment and placement of the original state-owned enterprise workers need the development of emerging industries and labor-intensive industries, the improvement of the minimum living guarantee and the system of employment training, namely the government should guarantee the reform of stateowned enterprises in these areas, and speed up the improvement of the supporting mechanism. Next, the Northeast State-owned resources can be revitalized by the capital market, in order to accelerate the core state-owned enterprises to be listed, realize the securitization of assets, and encourage enterprises to go public, making listed companies to become an important organizational form of state-owned enterprises. Besides, regional acquisitions, equity incentives, and employee stock ownership plans are effective measures to enhance the vitality of state-owned enterprises and the enthusiasm of employees in Northeast China.

\subsection{Transfer from Investment Driven to Innovation Driven, Enhancing the Driving Force of Economic Growth}

In order to further improve the environment for innovation and entrepreneurship in Northeast China, the government should actively create a policy condition that is conducive to innovation and entrepreneurship, which is encouraging innovation in industrial enterprises, protecting intellectual property rights, stimulating technical personnel's enthusiasm for innovation, improving infrastructure, attracting high-quality, innovative and entrepreneurial talents. Also, with the advantage of many universities in the northeast region, innovative talents can be actively cultivated through creating positive conditions for innovation and entrepreneurship policies to attract high-quality personnel, so that intellectual support and personnel support for the development of the local economy can be provided.

\subsection{Adjust the Investment Mode Actively, and Strengthen the Regional and International Cooperation}

Innovative investment model, simplified investment process, relaxing and positive environment for investment can accelerate the free flow of production factors among provinces with the policy coordination and industrial cooperation, so that to strengthen regional cooperation and resources exchange. Harbin, Changchun, Shenyang, Dalian are important node cities in the Mongolia and Russia economic zone and they have huge space in regional cooperation for deepening open. Secondly, through the regional cooperation to expand the market space, the strengthening of trade cooperation with Japan and South Korea contributes to the capital attraction from Russia and South Korea to the Northeast market, reversing the plight of the Northeast investment. Also, ideas can be transformed to develop the cooperation opportunities with other provinces and cities, encouraging the northeast manufacturing, agricultural products and processing industry to go out, and encouraging new industries, new commercial formats to come in.

\section{Conclusions}

The level of economic development in Northeast China has a direct impact on the overall development of China's economy. Whether the northeast region can maintain a stable development is related to the realization of industrialization and modernization in China. If the long-term economic growth of the northeast is always in the 
bottom, it will have a negative impact on China's long-term economic development. Therefore, it is necessary to pay great attention to the economic decline in Northeast China and take positive and effective strategies.

To achieve economic revitalization of Northeast China, those are not only needed like macro planning, policy support, promoting the development of third industry and the reform of state-owned enterprises by the state and government. Also, full participation of private capital and creativity of millions people are needed to inspire further development of market economy, to achieve innovation driven economic development and promote private economic development. From the point of their own reasons, the key to solve the problem of economy in the northeast region is the reform of system and mechanism, so that the barriers of the market economy can be broke down, and an active market system can be established. Making full use of the positive surrounding environment and promoting the establishment of a new investment model contributes to the establishment of export-oriented economy actively. By "reform inside, and open to the outside" strategy and promoting in two levels collaboratively, the economic recovery to steady and rapid development in northeast region has the possibility to be achieved, which can support China's economy to achieve stable and balanced development.

The innovations of this paper are as follows. First of all, this paper analyzes the economy problems of Northeast China in a complete structure and the analysis is relevantly clear. Secondly, this paper gives some innovative advice on the reform of economy structure, and sets up new mode to attract investment so as to solve these problems. In the future, the conclusion can be verified by an empirical research based on the enough data.

\section{References}

[1] Cui, M.X. (2016) Reasons and Countermeasures of Economic Growth in Northeast China. Innovation and Application in Science and Technology, 18, 31-32 (in Chinese).

[2] Liu, Y. (2016) Characteristics and Causes of Economic Downturn in Northeast China. Macro Economic Management, No. 8, 47-49 (in Chinese).

[3] Li, Q.S. (2016) The Present Situation and Thinking of Economy in Northeast China. Innovation and Application in Science and Technology, No. 2, 184-185 (in Chinese).

[4] Liu, Y. (2015) Strategic Thinking on Economic Transformation and Upgrading in Northeast China. Macro Economic Management, No. 8, 43-50 (in Chinese).

[5] Qiu, Z.Z. (2015) The Dilemma and Way out of Industrial Upgrading in Northeast China. China Opening Journal, No. 1, 57-60 (in Chinese).

[6] NDRC (2015) Opinions on the Implementation of the Innovation and Entrepreneurship Development of the Northeast Old Industrial Base to Create a New Competitive Advantage. 2015-1488.

\section{Submit or recommend next manuscript to SCIRP and we will provide best service for you:}

Accepting pre-submission inquiries through Email, Facebook, LinkedIn, Twitter, etc.

A wide selection of journals (inclusive of 9 subjects, more than 200 journals)

Providing 24-hour high-quality service

User-friendly online submission system

Fair and swift peer-review system

Efficient typesetting and proofreading procedure

Display of the result of downloads and visits, as well as the number of cited articles

Maximum dissemination of your research work

Submit your manuscript at: http://papersubmission.scirp.org/ 